Computation of aortic blood flows with consideration of vessel wall deformations

$\begin{array}{lrllll}\text { 学 } & \text { ○石渡 } & \text { 大介 (千葉大学) } & \text { 正 } & \text { 坪田 } & \text { 健一 (千葉大学) } \\ \text { 正 } & \text { 菅原 } & \text { 路子 (千葉大学) } & \text { 正 } & \text { 劉 } & \text { 浩 (千葉大学) }\end{array}$

Daisuke ISHIWATA, Graduate school of Engineering, Chiba University, 1-33,Yayoicho, Inageku, Chiba, Japan Ken-ichi TSUBOTA, Graduate school of Engineering, Chiba University, 1-33, Yayoicho, Inageku, Chiba, Japan Michiko SUGAWARA, Graduate school of Engineering, Chiba University, 1-33, Yayoicho, Inageku, Chiba, Japan Hao LIU, Graduate school of Engineering, Chiba University, 1-33, Yayoicho, Inageku, Chiba, Japan

Key words: Blood Vessel, Computing Fluid Dynamics, Pressure wave, Vessel wall deformation, Coupling Problem

\section{1. 锗吾}

心臟血管系の中, とくに大動脈のような大血管は心臟の駆 動や血流の拍動に起因した血流・血管壁の相互作用により通 常血管径 $10 \%$ 程度の変形が伴う。これまでは、血流・血管壁 の連成解析を必要とするこの血管壁変形を考慮した血行力 学的研究はあまり行われていない.

本研究では, ヒト動脈血管系全身 1 次元血行力学モデル と局所的 3 次元力学モデルをカップリングすることにより, 大動脈等の大血管系における血流・血管壁の連成解析計算 手法を開発し，大動脈内の血流動態や変形血管壁上におけ るずり応力の変換などを定量的に評価することを目的とす る.

\section{2. 辢手法}

(1) 1 次元モデル

心臟血管系血管壁の弾性変形を計算するために上海交通 大学の梁氏の開発された 1 次元モデル(2)を用いた. 1 次元モ デルは循環器系全身の血管網を電気回路による閉ループで 表現して，各血管を抵抗などの要素として方程式を立てて 計算を行う。この方程式を各血管ごとに Runge-kutta 法によ り解いていく。これにより時間ごとに各血管内の流量や圧 力, そして血管半径などを取得し, 本研究の 3 次元血流解 析に用いることにした。この手法では，各血管壁の弾性変 形が軸対称になっているが，各血管内における拍動波の伝 播や血管壁の変形を合理的に見積もることが可能であり，

しかも血流解析の 3 次元モデルに取り込むことが容易であ る利点がある。

(2) 3 次元モデル

血管イメージベストモデルを構築するために，血管壁の 座標データを元にして，血管の断面に対してＯ型になるよ うに，血管の芯線軸に対して対象に格子の生成をする. 本 研究では血管壁近傍での血流解析が重要となっているので, 壁に向かうにつれて格子間隔が小さくなるようにした．本 研究のように分岐のある血管では，オーバーセット格子法 により血管ごとに格子を構築している. 3 次元血管モデル の血管壁は 1 次元モデルにより計算された軸対称な血管径 を用い，与えられた移動境界問題として各時刻に更新する. 分岐部の変形に対して数值安定性を図るために，相似則が 導入され効率的にその変形と計算格子の再構築を行う. 流 出部については発達した Womersley 解を与えているため, 発達に十分な助走距離を考慮して作製した。

血液を非圧縮のニュートン流体とみなし, 非定常のナビ エストークス方程式を支配方程式としてコンピュータで解 くことにより 3 次元流体解析を行う. 解法としては, 完全
保存型の N-S 方程式と擬似圧縮法を導入した連続の式を有 限体積法で離散化した後, 時間進行法により各時間ステッ プについて十分収束するまで繰り返し計算を行なうことで 解いていく ${ }^{(3)}$.

計算条件としては, Table. 1 に示す, レイノルズ数 Re, ス トローハル数 $\mathrm{St}$, 変動周期 $\mathrm{T}$, 血液密度 $\rho$ および粘性係数

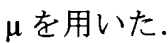

Table.1 Computational Parameters

\begin{tabular}{|l|r|}
\hline レイノルズ数 $\mathrm{Re}$ & 860 \\
\hline ストローハル数 $\mathrm{St}$ & 0.16 \\
\hline 変動周期 $\mathrm{T}[\mathrm{sec}]$ & 1.00 \\
\hline 血液密度 $\rho\left[\mathrm{g} / \mathrm{cm}^{3}\right]$ & 1.055 \\
\hline 粘性係数 $\mu\left[\mathrm{g} /\left(\mathrm{cm}^{*} \mathrm{sec}\right)\right]$ & 0.049 \\
\hline
\end{tabular}

\section{T字管モデル}

本 1 次元・ 3 次元モデルを検証するために, Fig.1 に示す ような分岐部をもつ $\mathrm{T}$ 字管内の壁変形を考慮した 3 次元血 流解析を試みた. 親管および娘管は真っすぐである.また, 大動脈弓部は大動脈と頸動脈などとが殆ど垂直に分岐して いること考慮し, 分岐角が 90 度のモデルを作成した. 分岐 部分についてはスムージング処理を施し， 2 つの血管をな めらかに接合した。

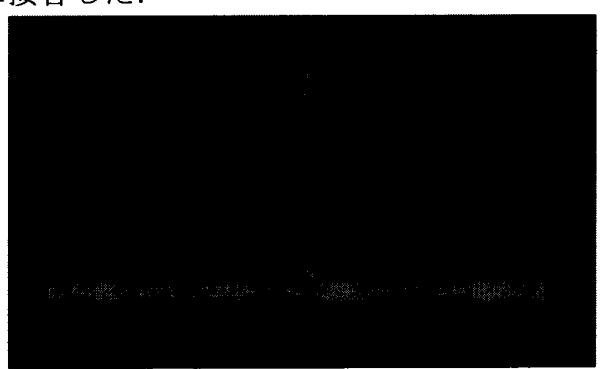

Fig.1 A T-shaped tube model

各血管の流量および血管各位置の半径の変化率を境界条 件として適用した．親管の入口および親管と娘管の出口の 流量を Fig.2(a)に, 各血管の各位置における半径変化率のう ち中央の值を Fig.2(b)に示す.血管壁を変形させただけでは, 分㞳部分にずれが生じてしまう。そこで娘管を親管の変形 に合わせて長さ方向に移動させることで, 分岐部分のずれ を小さくでき，安定した計算を行うことが可能である. な お, 各血管の長さ方向の変形は, 半径方向に比べて微少な ため変形はなしとした. 


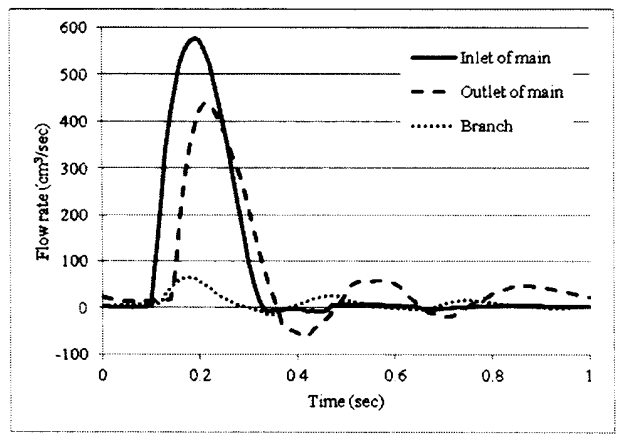

(a) Flow-volumetric rate waveforms

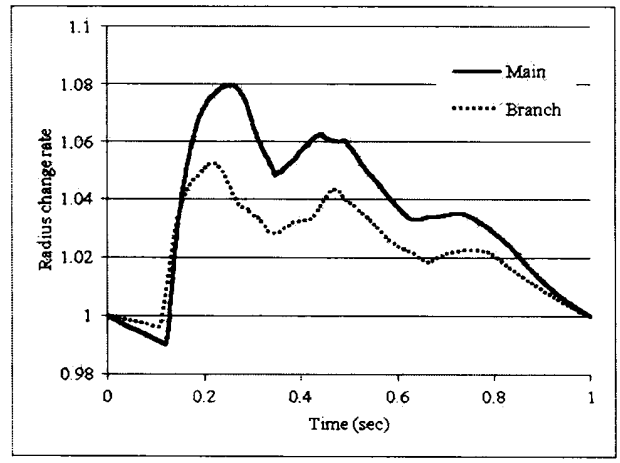

(b) Variation of vessel radii in a heart beat

Fig.2 1D model-based flow-volumetric rates and time-varying vessel radii in a T-shaped tube

\section{4. 县胍血管モデル}

心臟の左心室から始まる大動脈弓を親管として, 腕頭動 脈, 左総頸動脈, 左鎖骨下動脈を娘管に持つ, 4 本の動脈 血管を解析対象として，血管モデルを作製した，健常者の CT 画像から医用画像処理ソフト Image Realia(サイバネッ 卜社)を用いて血管部分を抽出し， 3 次元 CAD ソフト Rhinoceros(Appli Craft 社)を用いて血管壁および中心線の座 標を取得した.このデータを元に本研究室で開発した格子 生成プログラムを用いて格子を生成して，作製したモデル を Fig.3 に示す. 分岐部分についてはスムージング処理を 施すことで，なめらかな曲線の再現を行った。
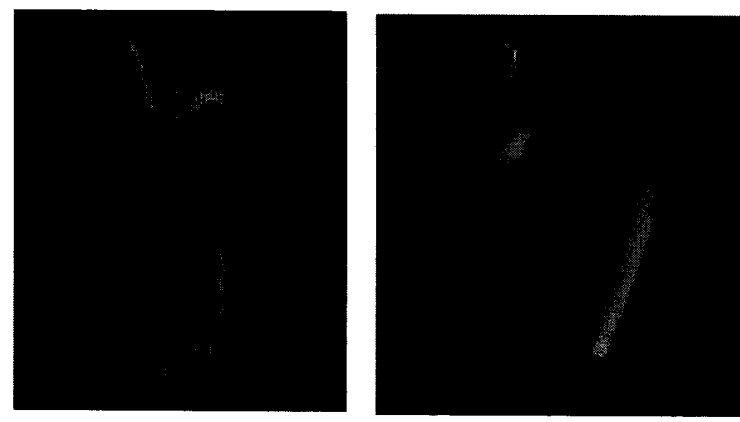

Fig.3 An aortic arch model

動脈血管モデルの変形は， $\mathrm{T}$ 字管モデルと同様に親管の 変形に対して娘管の全ての格子を親管に対して垂直に移動 することで, 親管との重なっている格子のずれを最小限に 抑えた．境界条件として親管入口および親管と各娘管の出 口の流量を Fig.4(a)に, 各血管の各位置における半径変化率 のうち中央の值を Fig.4(b)に示す. ただし, 親管流入部側か ら娘管 1，2および3とした。

\section{5. 轺果}

解析結果については可視化ソフト Field View(VINAS 社) を用いた。 $\mathrm{T}$ 字管モデルでは, 壁近傍で変形に伴い半径方 向の流速が生じていた. 分岐部分では流体がスムーズに流 れていたことから，計算手法としての基本が検証できた。

大動脈モデルでも同様に, 壁近傍において半径方向に流 速が発生していることが確認できる. 分岐部分での流れが スムーズであり, 大動脈弓モデルでも妥当な計算手法であ ることが確認できた。

\section{6. 結吾}

本研究では心臓血管系の 1 次元・ 3 次元モデルのカップ リングによる血流・血管壁の連成解析計算手法を開発し, $\mathrm{T}$ 字管内や大動脈弓内の血流動態の解析を通じてその妥当 性を確認した。今後は大動脈をはじめ, 頸動脈や脳動脈な どにこの手法を適用し心臟血管系各部位における血流の拍 動と血管壁変形による血流動態や血管壁表面ずり応力分布 などとの相関を明らかにするここと目指す。

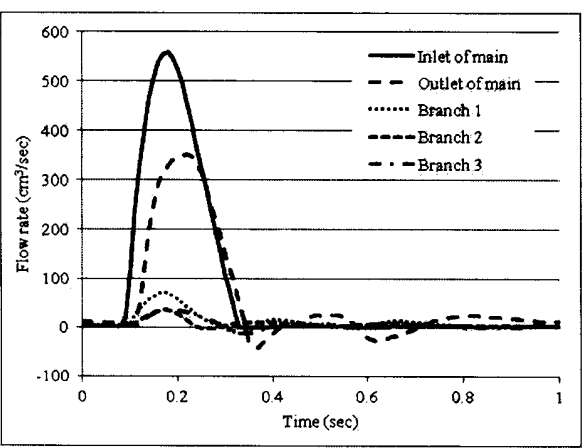

(a) Flow-volumetric rate waveforms

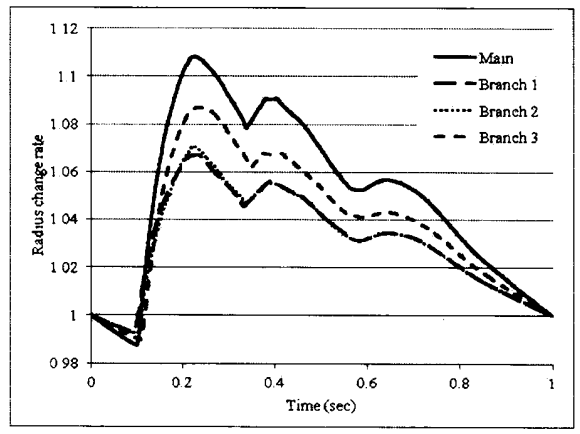

(b) Variation of vessel radii in a heart beat

Fig.4 1D model-based flow-volumetric rates and time-varying vessel radii in an aortic arch model

\section{期辞}

本研究の一部は, 独立法人科学技術振興機構次世代生命体 統合シミュレーションソフトウェアの研究開発 (臟器全身ス ケール・システム循環統合シミュレーション) 委託研究の助 成を得て行なわれ, ならびに様々な助言, ご指導くださった 研究室の関係各位に謝意を表す。

\section{考文献}

(1)http://www.mhlw.go.jp/toukei/saikin/hw/jinkou/geppo/nengai 10/kekka03.

(2)F.Liang and H.Liu, A closed-loop lumped parameter computational model for human cardiovascular system, JSME Intl Journal Series C.48, pp. 484-493(2005).

(3)H.Liu, Multi-scale computation in hemodynamics, RIKEN Symp. Computational Biomechanics, pp.147-154(2002). 